INSIGHTS INTO REGIONAL DEVELOPMENT

ISSN 2669-0195 (online) http://jssidoi.org/IRD/

2021 Volume 3 Number 4 (December)

http://doi.org/10.9770/IRD.2020.3.4(5)

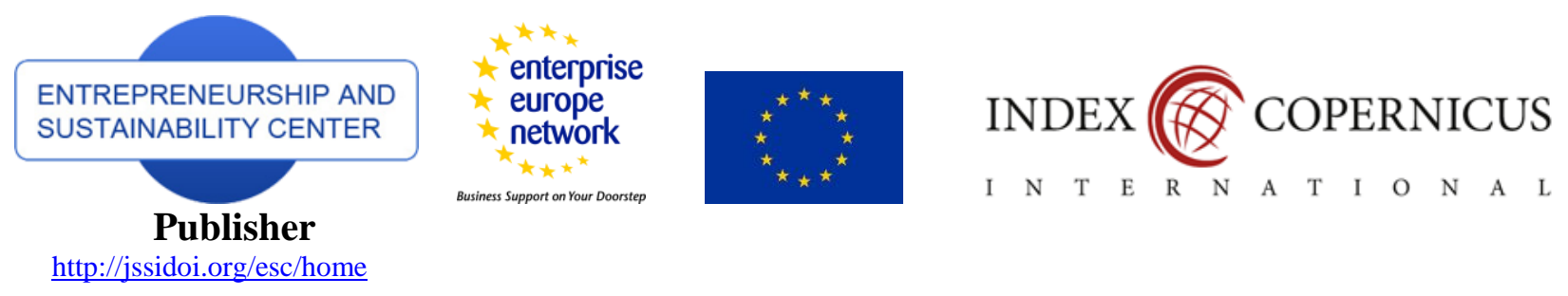

\title{
FOOD CONSUMPTION KNOWLEDGE AND HABITS IN A DEVELOPING COUNTRY: A CASE OF LEBANON*
}

\author{
Nada Mallah Boustani ${ }^{1}$, Manuela Ferreira ${ }^{2}$, Raquel P. F. Guiné ${ }^{3}$ \\ ${ }^{1}$ Faculty of Business \& Management, Saint Joseph University, Social Science Campus, Beirut, Lebanon \\ ${ }^{2}$ UICISA: E Research Centre, Health School, Polytechnic Institute of Viseu, 3504-510 Viseu, Portugal \\ ${ }^{3}$ CERNAS Research Centre, Department of Food Industry, Polytechnic Institute of Viseu, 3504-510 Viseu, Portugal \\ E-mails: ${ }^{1}$ nada.mallahboustany@usj.edu.lb; ${ }^{2}$ mmcferreira@gmail.com; ${ }^{3}$ raquelguine@esav.ipv.pt
}

Received 11 October 2021; accepted 29 November 2021; published 30 December 2021

\begin{abstract}
This research work investigated the Lebanese consumers' knowledge about food fibre and their food habits according to age groups and gender. The study was conducted from January 2021 till end of March 2021. Due to the pandemic of Covid-19 and the lockdown, the questionnaire was administered randomly through social media. The survey consisted of a longitudinal study carried out on a non-probabilistic convenience sample of 258 Lebanese participants. The responses were used to undertake a quantitative, descriptive and analytical study. The questionnaires received and considered valid, were mostly from women (59.7\%) and essentially living in an urban environment (78.3\%). To analyse the data, basic descriptive statistics were considered on a first level. Additionally, statistical tests were also carried out (Student $t$ test for comparisons between two groups). Finally, results and analysis were done to evaluate the importance of food knowledge among these people in addition to their eating habits and the possible gender differences. The results revealed that there are some gender inequalities $(\mathrm{F}=6.238, \alpha=0.0013)$ in terms of knowledge about food fibre, but no living environment differences were found $(\mathrm{F}=0.36, \alpha=0.85)$. Additionally, consumption habits showed major differences between female and male food behaviour, especially when it comes to eating: the frequency of eating outside from home, eating fast food and consuming fruits. The value of this study focuses on the food knowledge and habits in Lebanon, specifically in a country defined by a multi-ethnical diversity and religiosity and where food habits were mainly related to social behaviour. Therefore, this study adds more knowledge about these people's food behaviour and valuable information about specific food attitudes.
\end{abstract}

\footnotetext{
* This work was an extension of the project PROJ/CI\&DETS/2014/0001 form CI\&DETS Research Centre at the Polytechnic Institute of Viseu. The authors acknowledge financial support from the Portuguese Foundation for Science and Technology (FCT) within the scope of the projects Ref ${ }^{a}$ UIDB/00681/2020 and Ref ${ }^{a}$ UIDB/00742/2020. Furthermore, we would like to thank the CI\&DETS, CERNAS and UICISA: E Research Centres and the Polytechnic Institutes of Viseu for their support.
}
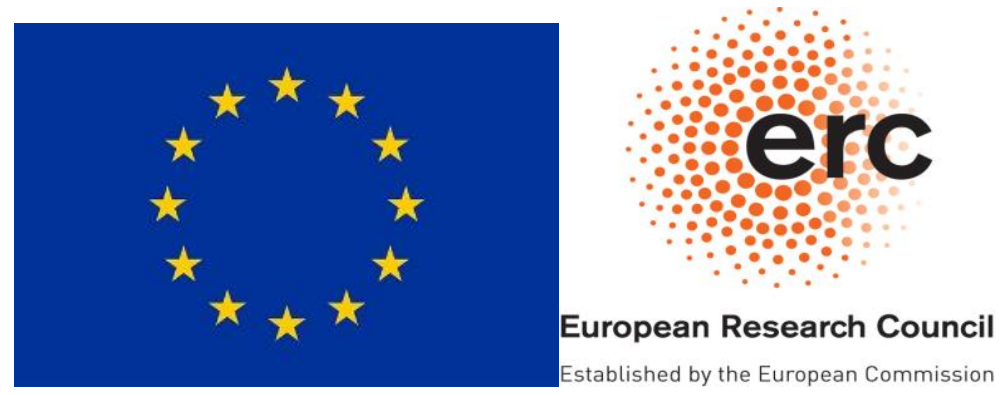


\title{
INSIGHTS INTO REGIONAL DEVELOPMENT
}

ISSN 2669-0195 (online) http://jssidoi.org/jesi/

2021 Volume 3 Number 4 (December)

http://doi.org/10.9770/IRD.2020.3.4(5)

\begin{abstract}
Keywords: Lebanese consumers; social behaviour; eating habits; food knowledge; fast food; food fibre
\end{abstract}
Reference to this paper should be made as follows: Boustani, N.M., Ferreira, M., Guiné. R.P.F. 2021. Food consumption knowledge and habits in a developing country: a case of Lebanon. Insights into Regional Development, 3(4), 62-79. http://doi.org/10.9770/IRD.2021.3.4(5)

JEL Classifications: I100, I115, I112

Additional disciplines: Public health; Regional development; Information

\section{Introduction}

Researchers address various changes in the knowledge about food components and the eating habits among variety of civilizations and the diversity of green, organic, rich in fibres and sustainable product purchase and consumption behaviour among people. One of the key components of food literacy is food knowledge and a cultural merge of nutritional, health and environmental knowledge (Azevedo Perry et al., 2017). It has been widely demonstrated that the possession of good levels of food knowledge positively influences eating behaviours (Wijayaratne et al., 2018). However, it is still unclear whether food knowledge is more effective in promoting healthy eating habits (Truman et al., 2017). The relationship between food knowledge and purchase behaviour has received experimental attention over the last decade (National Academies of Sciences, Engineering, and Medicine, 2016), whereas procedural skills such as food preparation and declarative knowledge like the information about nutritional properties of food are both instrumental for boosting healthy behaviours (Kolasa et al., 2001).

Furthermore, a noticeable phenomenon about young generations (Generation Y aged from 18 to 35 years) eating habits exhibit their powerful cohort in the restaurant industry (Yoon \& Chung, 2018) where a significant percentage of their expenditure is spent on dining out activities (Nyheim et al., 2015). They dine out twice as much as the rest of the population and spend more money on eating out. This fact is very important to the researchers because understanding consumer preferences and consumer segments in a market-based economy is crucial and some broad assessments have been done to understand these needs and preferences (Okumus et al., 2021; Rosenbaum et al., 2015). It is important to identify the consumer's expectations and build appropriate marketing strategies in the world of business and restaurants industry. These young generation's concerns regarding their health are increasing (Y.-H. C. Sun, 2008). Members of this cohort view themselves as health conscious and adventurous (Roseman et al., 2017). They prefer green restaurants, healthy menus and quality foods (Jang et al., 2011). Additionally, they spend a greater proportion of their income on prepared foods and cook at home from scratch less frequently than earlier cohorts (Namin et al., 2020). They also eat out more, and spend more when they do, than other cohorts. They view dining out as an experience (Hammond et al., 2013) and want to enjoy a nice meal out, even when financially short. They also appreciate the social aspects of dining out and prefer communal tables at restaurants where either they eat in large groups of friends and colleagues, or they are seated with strangers. Aligned with the evident increase in the income and wealth, eating out has become more and more popular in todays' society, particularly in developed counties (Kolanowski et al., 2020).

Lately, a nutritional transition in food choices has been observed in Lebanon, shifting from the traditional Mediterranean diet to the globalized fast-food pattern. Consequently, young adults' dietary habits have been particularly impacted. A study conducted by Nyheim et al. (Nyheim et al., 2015) about Lebanese obesity problems among university students showed that overweight and obesity are more and more frequent among young people, which, combined with unhealthy lifestyles, such as smoking and physical inactivity, can increase substantially the risk of chronic diseases. Hence, nutritional knowledge specifically about food fibres may act as a deterrent against these changes in food habits. Furthermore, awareness campaigns aimed at increasing the level of knowledge about food may be decisive to significantly reduce the prevalence of obesity and chronic diseases 


\section{INSIGHTS INTO REGIONAL DEVELOPMENT}

ISSN 2669-0195 (online) http://jssidoi.org/jesi/

2021 Volume 3 Number 4 (December)

http://doi.org/10.9770/IRD.2020.3.4(5)

among Lebanese population, through the promotion of healthy eating habits specially in a developing country. On the other hand, and in terms of eating habits, a study conducted at Midwestern University on a sample of 286 students (105 male and 181 female), reported that $94.4 \%$ of the participants recognize the importance of eating a variety of foods for improved health (Davy et al., 2006). In another study, healthful diet was classified as a diet that included more fruits and vegetables, and less fat (Wardle et al., 2004). The unhealthy eating habits of younger generation were noticed in the intake of fried food, in a developed country (Yahia et al., 2008).

To the best of the authors knowledge, no prior study combined the two questions of knowledge about food fibres and the food habits consumptions in order to investigate food choices and awareness about food components among Lebanese citizens. Also, the authors did not find any previous study exploring consumers' sociodemographic profiling, in terms of age and gender and living environment, in relation to food knowledge about fibres components and eating habits. The authors think that the assessment of consumers sociodemographic profiling might bring new insights into the understanding of food purchase behaviour and healthy lifestyles promotion. The present study intends to contribute to the existing literature by addressing the associations between food knowledge and eating habits in Lebanon and it will add more knowledge to a previous study conducted on Lebanese people motivational eating factors (Yahia et al., 2008). Lebanese food consumption habits and their level of knowledge on food fibres may improve their eating habits by promoting the adoption of healthier food choices.

The purpose of this study is to assess Lebanese eating habits and to investigate the Lebanese consumers' knowledge about food fibre according to gender and age, looking for differences between generation X (aged 35 years or more) and $\mathrm{Y}$ (between 18 and 35 years).

\section{Materials and Methods}

This research was undertaken on a non-probabilistic convenience sample of 273 Lebanese participants. However, only 258 questionnaires were considered valid to include in this quantitative, transversal, descriptive and analytical study. It was conducted from January 2021 till end of March 2021. Due to the pandemic of Covid-19 and the lockdown, the questionnaire was administered randomly through social media. We used the Google Forms to collect the survey responses, which is common and friendly to most Lebanese people enabling all our respondents to answer easily all the questions. By using the internet to disclose the questionnaire we targeted people with access to internet and computer or other mobile devices. The latest estimate dated February 2021 held by the Datareportal Digital 2021 Lebanon (Digital in Lebanon, sem data) indicates that $78.2 \%$ of Lebanese people can access the Internet at home, via any device type and connection (internet penetration), from a total population of 6.8 Million Lebanese citizens. We used a convenience sample, recruited according to facility and considering the restrictions of the COVID-19 pandemic. Although convenience samples are described as having some limitations, namely not allowing direct generalization of the conclusions from the sample to the whole population, it is also reported that they have some positive aspects, mostly the possibility to easy recruit participants, and they can be used to carry out exploratory research (R. P. F. Guiné, Florença, Barroca, et al., 2020; R. P. F. Guiné, Florença, Villalobos Moya, et al., 2020). Even though being a convenience sample, adequacy of the sample size was evaluated to serve as an indicator. For this, some assumptions were considered: $\bullet$ Confidence interval $=90 \%$, $\bullet \mathrm{Z}$ score $=1.65, \bullet$ Power of the test $=95 \%$ (minimum acceptable probability of preventing type II error $=0.05)$ (Levin \& Fox, 2004; Triola \& Flores, 2017), •Lebanese population $=6.8$ million (Digital in Lebanon, sem data): assuming that the target population was $30 \%$ of adults, and considering the above mentioned conditions, the minimum sample size was calculated as 229 respondents (Cochran, 1977; Levine et al., 2008). The number of valid questionnaires obtained in this survey was 258 , which is over the minimum.

The conducted research was approved on the 15th of May 2020 Reference number USJ-2020-89. The study is integrated in an international project lead by CI\&DETS research centre of the polytechnic institute of Viseu in 


\section{INSIGHTS INTO REGIONAL DEVELOPMENT}

ISSN 2669-0195 (online) http://jssidoi.org/jesi/

2021 Volume 3 Number 4 (December)

http://doi.org/10.9770/IRD.2020.3.4(5)

Portugal (Boustani \& Guiné, 2020). The questionnaire included different parts as follows: •Demographics (4 items) (age; education; gender; living environment); •Consumption habits (5 items) whose answer was given as frequency of consumption per week; $\bullet$ Knowledge about food fibres ( 6 items), whose answerers were given on a 5-point Likert scale.

Data processing was carried out using IBM Statistics (Statistical Package for the Social Sciences SPSS v24). Different statistical techniques were used to treat the data. On a first step the normality of the distribution was assessed by measuring Skewness (SK) and Kurtosis (K). As for the central tendency, the researchers focused on mean, standard deviation and coefficient of variation. The crosstabs tool was also used to analyse and report data across groups. Results were expressed as means \pm standard deviation (SD). Parametric variables were analysed using students' t-test to examine differences in the characteristics of respondents across groups. All reported P values were made on the basis of 2-sided tests and compared to a significance level of 5\%; differences were considered statistically significant at $\mathrm{P}<0.05$.

The questions about consumption were as follows: How many meals do you have in a week that include vegetables and/or salads? How many pieces of fruit do you eat per week? How often do you eat outside from home per week? How many times a week do you eat fast food? How many times a week do you eat whole grains (whole-wheat bread, whole-wheat pasta ...)? Given the dispersion of possible values, for presentation of of the results, the answers given by the participants to these questions were grouped into categories according to each type. For the consumption of fruits/vegetables\&salads/whole cereals the categories were: 2-3 times per day, 1 time per day, 4-5 times per week, 2-3 times per week, 1 time per week, 1 time per month, Never. For variables eating out and fast-food consumption the categories were: 1 time per day, 4-5 times per week, 2-3 times per week, 1 time per week, 1 time per month, Never. Note that for some cases some of the categories were empty, meaning that there were not any answers falling into that category. For the evaluation of gender or age differences, a mean value for each of the variables was computed as an average from all the answers of the participants, and these mean values were submitted to a parametric test for comparison of means between two groups (T-test).

In the case of knowledge, the variables were: Fibres are naturally present in vegetable foods; Foods of animal origin have no fibres (unless added); The average adult should eat $25 \mathrm{~g}$ of fibre per day; Whole foods have less fibre than non-whole foods; The unpeeled fruits have less fibre than peeled ones; Dietary fibres are classified into soluble and insoluble. For all these the respondents were asked to indicate their level of agreement on a 5 points Likert scale as follows: $1=$ strongly disagree, $2=$ disagree, $3=$ neither agree nor disagree, $4=$ agree, $5=$ strongly agree. In this case, to evaluate the gender or age differences also a mean value was calculated for each of the questions as an average from all the answers. Again, the parametric T-test was used to compare the means of the different groups being compared.

The research questions of our research are the following:

RQ1: What are the food habits among the Lebanese women and men?

RQ2: what is the knowledge about food fibres among the Lebanese women and men?

RQ3: Are there any gender differences in the knowledge about food fibres and in Lebanese consumer habits?

RQ4: Are there any age differences in the knowledge about food fibres and in Lebanese consumer habits? 


\section{INSIGHTS INTO REGIONAL DEVELOPMENT}

ISSN 2669-0195 (online) http://jssidoi.org/jesi/

2021 Volume 3 Number 4 (December)

http://doi.org/10.9770/IRD.2020.3.4(5)

\section{Results}

\subsection{Sociodemographic characterization}

Table 1 presents the demographical data for the sample studied. Having in mind to compare the $\mathrm{X}$ and $\mathrm{Y}$ generations, as mentioned above, the variable age was classified into these two categories. So, there were almost half of the participants in each of the classes, with $51.9 \%$ in the young category and $48.1 \%$ being aged and from 36 and above. Also, the gender distribution is relatively even, with 59.7\% women and $40.3 \%$ men. However, for education level and for living environment the groups were highly different, with an expressive majority of participants holding a university degree $(93.0 \%)$ and living in an urban environment (78.3\%). Therefore, given that the distribution of the participants in this study was almost equitable in terms of gender and age and categories, the researchers focused on the study about the variables of food consumption habits and knowledge of the Lebanese across these groups, rather than those groups where the representativeness was not so even. Our sample was found relatively representative of the Lebanese population, since, Lebanon demographic traits are as follows for gender: $49.6 \%$ of women versus $50.4 \%$ of men. Hence Lebanon has approximately half women while in our sample we have about $60 \%$, so the sample can be considered representative of the gender distribution in Lebanon. As for the living environment: $89.0 \%$ of Lebanon's population lives in urban centers, while $11.0 \%$ live in rural areas, and again this sample is representative of the Lebanese demographic living areas.

Table 1. Sociodemographic characterization of the study sample

\begin{tabular}{llcc}
\hline Variable & Group & Frequency & Percent \\
\hline Age & 18 to 35 years (Class Y) & 134 & 51.9 \\
& Over 35 years (Class X) & 124 & 48.1 \\
\hline Education & Secondary school & 18 & 7.0 \\
& University degree & 240 & 93.0 \\
\hline Sex & Female & 154 & 59.7 \\
& Male & 104 & 40.3 \\
\hline Living environment & Rural & 56 & 21.7 \\
& Urban & 202 & 78.3 \\
\hline Total & & 258 & 100 \\
\hline
\end{tabular}

\subsection{Food consumption habits among the Lebanese women and men}

A cross sectional analysis for the set of questions related to food habits was conducted to answer research question RQ1. The results in Table 2 show that an expressive majority of the surveyed Lebanese people (84.1\%) consume fruits regularly (more than 3 times per week), regardless of gender ( $\lesssim 79.7 \% \mathrm{vs}+87.0 \%$ ). With regards to the consumption of vegetables and salads, it appears that $58.7 \%$ of men and $63.6 \%$ of women eat salad daily. As for daily whole cereals consumption accounts for only $27.6 \%$, slightly higher in women $(\widehat{\sigma} 20.2 \%$ vs $O$ $32.5 \%)$. When asked whether they eat out more than two times per week, $29.9 \%$ responded affirmatively more for

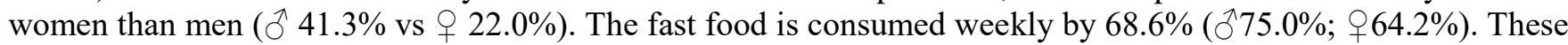
results show a certain awareness and good food consumption habits for Lebanese people as of high percentages of healthy food intake. The researchers' main concern is about the fast-food consumption, which represents a high percentage of frequent fast-food intake. It appears that most women (53.2\%) eat outside just once per week whereas men visit restaurants more often (just $40.4 \%$ once per week), this might be due to their different lifestyle or work situation.

In a similar study by Guiné et al. (2020) undertaken on six countries (Argentina, Croatia, Hungary, Latvia, Portugal and Romania) it was found that $78.2 \%$ of the participants had a low consumption of vegetables and salads and also of fruits (for $92.3 \%$ of participants). Regarding whole cereals, $23.1 \%$ of participants never consumed them and $72.6 \%$ has a low consumption. In the same work (R. P. F. Guiné, Florença, Leal, et al., 2020) 
INSIGHTS INTO REGIONAL DEVELOPMENT

ISSN 2669-0195 (online) http://jssidoi.org/jesi/

2021 Volume 3 Number 4 (December)

http://doi.org/10.9770/IRD.2020.3.4(5)

the authors found variations in the consumption of vegetables, salads, fruits and whole cereals across genders and age groups, as well as across countries. In a recent survey by Lee and Pena-y-lillo (Lee \& Pena-y-Lillo, 2021), for US participants, it was found that vegetable and fruit consumption were positively correlated with education and income, meaning that higher education level and higher income were factors that contributed to an increase consumption of these foods. The same authors also reported that these observed differences across social groups are explained by communication inequalities, which are linked with the level of information. The social cognitive theory emphasizes the critical role that cognitive processes have in shaping the human behaviour. According to this theory, a person considers cognitive, social, and environmental factors to define their motivations, including the motivations for food choice (Bandura, 1999). In the work by Garcia et al. (2021) are explored the cognitive factors associated with the frequency of eating outside from home, by using multinomial models to compute relative risk ratios. They found that for every 1-unit increase in mindfulness disposition, the risk of a participant eating out every week compared with every month decreased by a factor of 0.42 . Similar results indicated that other factor besides mindful disposition also contributed to the increased frequency of eating out, namely, the higher nutrition knowledge. Contrarily, the self-efficacy resulted in a decreased frequency of eating outside from home.

Table 2. Reported food consumption habits according to gender

\begin{tabular}{|c|c|c|c|c|c|c|}
\hline & \multicolumn{2}{|c|}{ Women } & \multicolumn{2}{|c|}{ Men } & \multicolumn{2}{|c|}{ Global sample } \\
\hline & $\mathbf{N}$ & $\%^{(1)}$ & $\mathbf{N}$ & $\%^{(1)}$ & $\mathbf{N}$ & $\%^{(1)}$ \\
\hline \multicolumn{7}{|c|}{ Frequency of consuming fruits } \\
\hline $2-3$ times per day & 45 & 29.2 & 25 & 24.0 & 70 & 27.1 \\
\hline 1 time per day & 43 & 27.9 & 28 & 26.9 & 71 & 27.5 \\
\hline 4-5 times per week & 46 & 29.9 & 30 & 28.8 & 76 & 29.5 \\
\hline 2-3 times per week & 17 & 11.0 & 16 & 15.4 & 33 & 12.8 \\
\hline 1 time per week & 3 & 1.9 & 5 & 4.8 & 8 & 3.1 \\
\hline \multicolumn{7}{|c|}{ Frequency of consuming vegetables and salads } \\
\hline 2-3 times per day & 43 & 27.9 & 29 & 27.9 & 72 & 27.9 \\
\hline 1 time per day & 55 & 35.7 & 32 & 30.8 & 87 & 33.7 \\
\hline 4-5 times per week & 18 & 11.7 & 19 & 18.3 & 37 & 14.3 \\
\hline 2-3 times per week & 26 & 16.9 & 22 & 21.2 & 48 & 18.6 \\
\hline 1 time per week & 12 & 7.8 & 2 & 1.9 & 14 & 5.4 \\
\hline \multicolumn{7}{|c|}{ Frequency of consuming whole cereals } \\
\hline $2-3$ times per day & 12 & 7.8 & 8 & 7.7 & 20 & 7.8 \\
\hline 1 time per day & 38 & 24.7 & 13 & 12.5 & 51 & 19.8 \\
\hline 4-5 times per week & 12 & 7.8 & 9 & 8.7 & 21 & 8.1 \\
\hline 2-3 times per week & 53 & 34.4 & 35 & 33.7 & 88 & 34.1 \\
\hline 1 time per week & 18 & 11.7 & 24 & 23.1 & 42 & 16.3 \\
\hline 1 time per month & 13 & 8.4 & 7 & 6.7 & 20 & 7.8 \\
\hline Never & 8 & 5.2 & 8 & 7.7 & 16 & 6.2 \\
\hline \multicolumn{7}{|c|}{ Frequency of eating out } \\
\hline 1 time per day & 3 & 1.9 & 12 & 11.5 & 15 & 5.8 \\
\hline 4-5 times per week & 8 & 5.2 & 4 & 3.8 & 12 & 4.7 \\
\hline 2-3 times per week & 23 & 14.9 & 27 & 26.0 & 50 & 19.4 \\
\hline 1 time per week & 82 & 53.2 & 42 & 40.4 & 124 & 48.1 \\
\hline 1 time per month & 38 & 24.7 & 19 & 18.3 & 57 & 22.1 \\
\hline \multicolumn{7}{|c|}{ Frequency of consuming fast food } \\
\hline 1 time per day & 3 & 1.9 & 4 & 3.8 & 7 & 2.7 \\
\hline 4-5 times per week & 1 & 0.6 & 6 & 5.8 & 7 & 2.7 \\
\hline 2-3 times per week & 22 & 14.3 & 29 & 27.9 & 51 & 19.8 \\
\hline 1 time per week & 73 & 47.4 & 39 & 37.5 & 112 & 43.4 \\
\hline 1 time per month & 47 & 30.5 & 20 & 19.2 & 67 & 26.0 \\
\hline Never & 8 & 5.2 & 6 & 5.8 & 14 & 5.4 \\
\hline Total & 154 & 100.0 & 104 & 100.0 & 258 & 100.0 \\
\hline
\end{tabular}

${ }^{(1)}$ Percentage within sex. 


\section{INSIGHTS INTO REGIONAL DEVELOPMENT}

ISSN 2669-0195 (online) http://jssidoi.org/jesi/

2021 Volume 3 Number 4 (December)

http://doi.org/10.9770/IRD.2020.3.4(5)

\subsection{Knowledge about food fibres among the Lebanese women and men}

In order to answer research question RQ2 concerning the level of knowledge about food fibres for both men and women, also a cross sectional analysis was made. In this, a set of questions (6 items) tested the level of knowledge of the participants; the questions were related to the existence of fibres in vegetable foods, in Foods of animal origin, in peeled or unpeeled fruits, the adult daily fibre consumption and the different classification of dietary fibres (soluble and insoluble). In the analysis of the statistics related to food literacy and knowledge, it appears that the level of knowledge is somehow low which is indicative that Lebanese people lack intervention in terms of healthy eating habits and don't have a wide vision about the existence of fibres in different types of food (Table $3)$. There are some differences in the percentages and distribution of the Likert scale replies of male and female participants in most answers. Regarding the presence of fibre in vegetable foods (a true statement), 22\% of men and $21 \%$ of women know this, so it is quite even for both genders. As to the absence of fibres in animal foods (also true), more women (65\%) know this than men (33\%). Concerning the recommended dose $25 \mathrm{~g}$ of fibre per day for adults, $41 \%$ of men know which is lower than the percentage of women $(65 \%)$. Regarding the lower fibre content of whole foods (this was given as a false information), again women are more informed than men ( $P$ $69.0 \%$ vs $740.0 \%$ disagree with the false information presented). Also, the fibre content of peeled and unpeeled fruits was presented as a false statement and the women were more informed than men, being able to recognize it was a false statement ( $+77.0 \%$ vs $\widehat{\gamma} 56.0 \%$ disagree). Finally, about the classification of fibre into soluble and insoluble, men and women showed some differences ( $+46.0 \%$ vs $\sigma^{\lambda} 40.0 \%$ ).

Regardless of the above-mentioned results, it is important to notice, a high proportion of respondents who answered "Neither agree nor disagree", showing that they are not able to express an opinion, lacking information about the topics. The work by Ferreira et al. (2016) undertaken on ten different countries, showed that mostly people get information about dietary fibre from the internet, although recognizing that television might be a most suitable way to disseminate this type of information. The work by Georgescu et al. (2019) revealed that percentage of correct answers regarding knowledge about health effects of dietary fibre were generally low.

Table 3. Reported food knowledge according to gender

\begin{tabular}{|c|c|c|c|c|c|c|c|}
\hline & & \multicolumn{3}{|c|}{$\begin{array}{l}\text { Fibres are naturally present in vegetable } \\
\text { foods. }\end{array}$} & \multicolumn{3}{|c|}{$\begin{array}{c}\text { Foods of animal origin have no fibres } \\
\text { (unless added). }\end{array}$} \\
\hline & & Women & Men & Total & Women & Men & Total \\
\hline Strongly & Count & 39 & 14 & 53 & 8 & 10 & 18 \\
\hline \multirow[t]{2}{*}{ disagree } & $\%$ within $\mathrm{Q}$ & $73.60 \%$ & $26.40 \%$ & $100.00 \%$ & $44.40 \%$ & $55.60 \%$ & $100.00 \%$ \\
\hline & $\%$ within Sex & $25.30 \%$ & $13.50 \%$ & $20.50 \%$ & $5.20 \%$ & $9.60 \%$ & $7.00 \%$ \\
\hline \multirow[t]{3}{*}{ Disagree } & Count & 74 & 55 & 129 & 38 & 38 & 76 \\
\hline & $\%$ within $\mathrm{Q}$ & $57.40 \%$ & $42.60 \%$ & $100.00 \%$ & $50.00 \%$ & $50.00 \%$ & $100.00 \%$ \\
\hline & $\%$ within Sex & $48.10 \%$ & $52.90 \%$ & $50.00 \%$ & $24.70 \%$ & $36.50 \%$ & $29.50 \%$ \\
\hline & Count & 20 & 13 & 33 & 43 & 23 & 66 \\
\hline \multirow[t]{2}{*}{ nor disagree } & $\%$ within Q & $60.60 \%$ & $39.40 \%$ & $100.00 \%$ & $65.20 \%$ & $34.80 \%$ & $100.00 \%$ \\
\hline & $\%$ within Sex & $13.00 \%$ & $12.50 \%$ & $12.80 \%$ & $27.90 \%$ & $22.10 \%$ & $25.60 \%$ \\
\hline \multirow[t]{3}{*}{ Agree } & Count & 16 & 15 & 31 & 51 & 25 & 76 \\
\hline & $\%$ within $\mathrm{Q}$ & $51.60 \%$ & $48.40 \%$ & $100.00 \%$ & $67.10 \%$ & $32.90 \%$ & $100.00 \%$ \\
\hline & $\%$ within Sex & $10.40 \%$ & $14.40 \%$ & $12.00 \%$ & $33.10 \%$ & $24.00 \%$ & $29.50 \%$ \\
\hline \multirow[t]{3}{*}{ Strongly agree } & Count & 5 & 7 & 12 & 14 & 8 & 22 \\
\hline & $\%$ within $\mathrm{Q}$ & $41.70 \%$ & $58.30 \%$ & $100.00 \%$ & $63.60 \%$ & $36.40 \%$ & $100.00 \%$ \\
\hline & $\%$ within Sex & $3.20 \%$ & $6.70 \%$ & $4.70 \%$ & $9.10 \%$ & $7.70 \%$ & $8.50 \%$ \\
\hline \multirow{4}{*}{ Total } & Count & 154 & 104 & 258 & 154 & 104 & 258 \\
\hline & $\%$ within $\mathrm{Q}$ & $59.70 \%$ & $40.30 \%$ & $100.00 \%$ & $59.70 \%$ & $40.30 \%$ & $100.00 \%$ \\
\hline & $\%$ within Sex & $100.00 \%$ & $100.00 \%$ & $100.00 \%$ & $100.00 \%$ & $100.00 \%$ & $100.00 \%$ \\
\hline & & \multicolumn{3}{|c|}{$\begin{array}{l}\text { The average adult should eat } 25 \mathrm{~g} \text { of fibre } \\
\text { per day. }\end{array}$} & \multicolumn{3}{|c|}{$\begin{array}{l}\text { Whole foods have less fibre than non- } \\
\text { whole foods. }\end{array}$} \\
\hline
\end{tabular}


INSIGHTS INTO REGIONAL DEVELOPMENT

ISSN 2669-0195 (online) http://jssidoi.org/jesi/

2021 Volume 3 Number 4 (December)

http://doi.org/10.9770/IRD.2020.3.4(5)

\begin{tabular}{|c|c|c|c|c|c|c|c|}
\hline Strongly & Count & 2 & 4 & 6 & 26 & 18 & 44 \\
\hline \multirow[t]{2}{*}{ disagree } & $\%$ within Q & $33.30 \%$ & $66.70 \%$ & $100.00 \%$ & $59.10 \%$ & $40.90 \%$ & $100.00 \%$ \\
\hline & $\%$ within Sex & $1.30 \%$ & $3.80 \%$ & $2.30 \%$ & $16.90 \%$ & $17.30 \%$ & $17.10 \%$ \\
\hline \multirow[t]{3}{*}{ Disagree } & Count & 9 & 13 & 22 & 43 & 22 & 65 \\
\hline & $\%$ within $\mathrm{Q}$ & $40.90 \%$ & $59.10 \%$ & $100.00 \%$ & $66.20 \%$ & $33.80 \%$ & $100.00 \%$ \\
\hline & $\%$ within Sex & $5.80 \%$ & $12.50 \%$ & $8.50 \%$ & $27.90 \%$ & $21.20 \%$ & $25.20 \%$ \\
\hline Neither agree & Count & 78 & 46 & 124 & 34 & 27 & 61 \\
\hline \multirow[t]{2}{*}{ nor disagree } & $\%$ within $\mathrm{Q}$ & $62.90 \%$ & $37.10 \%$ & $100.00 \%$ & $55.70 \%$ & $44.30 \%$ & $100.00 \%$ \\
\hline & $\%$ within Sex & $50.60 \%$ & $44.20 \%$ & $48.10 \%$ & $22.10 \%$ & $26.00 \%$ & $23.60 \%$ \\
\hline \multirow[t]{3}{*}{ Agree } & Count & 49 & 31 & 80 & 41 & 29 & 70 \\
\hline & $\%$ within $\mathrm{Q}$ & $61.30 \%$ & $38.80 \%$ & $100.00 \%$ & $58.60 \%$ & $41.40 \%$ & $100.00 \%$ \\
\hline & $\%$ within Sex & $31.80 \%$ & $29.80 \%$ & $31.00 \%$ & $26.60 \%$ & $27.90 \%$ & $27.10 \%$ \\
\hline \multirow[t]{3}{*}{ Strongly agree } & Count & 16 & 10 & 26 & 10 & 8 & 18 \\
\hline & $\%$ within $\mathrm{Q}$ & $61.50 \%$ & $38.50 \%$ & $100.00 \%$ & $55.60 \%$ & $44.40 \%$ & $100.00 \%$ \\
\hline & $\%$ within Sex & $10.40 \%$ & $9.60 \%$ & $10.10 \%$ & $6.50 \%$ & $7.70 \%$ & $7.00 \%$ \\
\hline \multirow[t]{4}{*}{ Total } & Count & 154 & 104 & 258 & 154 & 104 & 258 \\
\hline & $\%$ within $\mathrm{Q}$ & $59.70 \%$ & $40.30 \%$ & $100.00 \%$ & $59.70 \%$ & $40.30 \%$ & $100.00 \%$ \\
\hline & $\%$ within Sex & $100.00 \%$ & $100.00 \%$ & $100.00 \%$ & $100.00 \%$ & $100.00 \%$ & $100.00 \%$ \\
\hline & & \multicolumn{3}{|c|}{$\begin{array}{l}\text { The unpeeled fruits have less fibre than } \\
\text { peeled ones. }\end{array}$} & \multicolumn{3}{|c|}{$\begin{array}{l}\text { Dietary fibres are classified into soluble } \\
\text { and insoluble. }\end{array}$} \\
\hline Strongly & Count & 44 & 22 & 66 & 8 & 4 & 12 \\
\hline \multirow{2}{*}{ disagree } & $\%$ within Q & $66.70 \%$ & $33.30 \%$ & $100.00 \%$ & $66.70 \%$ & $33.30 \%$ & $100.00 \%$ \\
\hline & $\%$ within Sex & $28.60 \%$ & $21.20 \%$ & $25.60 \%$ & $5.20 \%$ & $3.80 \%$ & $4.70 \%$ \\
\hline \multirow[t]{3}{*}{ Disagree } & Count & 33 & 34 & 67 & 15 & 18 & 33 \\
\hline & $\%$ within $\mathrm{Q}$ & $49.30 \%$ & $50.70 \%$ & $100.00 \%$ & $45.50 \%$ & $54.50 \%$ & $100.00 \%$ \\
\hline & $\%$ within Sex & $21.40 \%$ & $32.70 \%$ & $26.00 \%$ & $9.70 \%$ & $17.30 \%$ & $12.80 \%$ \\
\hline \multirow{3}{*}{$\begin{array}{l}\text { Neither agree } \\
\text { nor disagree }\end{array}$} & Count & 35 & 13 & 48 & 85 & 42 & 127 \\
\hline & $\%$ within Q & $72.90 \%$ & $27.10 \%$ & $100.00 \%$ & $66.90 \%$ & $33.10 \%$ & $100.00 \%$ \\
\hline & $\%$ within Sex & $22.70 \%$ & $12.50 \%$ & $18.60 \%$ & $55.20 \%$ & $40.40 \%$ & $49.20 \%$ \\
\hline \multirow[t]{3}{*}{ Agree } & Count & 32 & 28 & 60 & 34 & 25 & 59 \\
\hline & $\%$ within $\mathrm{Q}$ & $53.30 \%$ & $46.70 \%$ & $100.00 \%$ & $57.60 \%$ & $42.40 \%$ & $100.00 \%$ \\
\hline & $\%$ within Sex & $20.80 \%$ & $26.90 \%$ & $23.30 \%$ & $22.10 \%$ & $24.00 \%$ & $22.90 \%$ \\
\hline \multirow[t]{3}{*}{ Strongly agree } & Count & 10 & 7 & 17 & 12 & 15 & 27 \\
\hline & $\%$ within $\mathrm{Q}$ & $58.80 \%$ & $41.20 \%$ & $100.00 \%$ & $44.40 \%$ & $55.60 \%$ & $100.00 \%$ \\
\hline & $\%$ within Sex & $6.50 \%$ & $6.70 \%$ & $6.60 \%$ & $7.80 \%$ & $14.40 \%$ & $10.50 \%$ \\
\hline \multirow[t]{3}{*}{ Total } & Count & 154 & 104 & 258 & 154 & 104 & 258 \\
\hline & $\%$ within Q & $59.70 \%$ & $40.30 \%$ & $100.00 \%$ & $59.70 \%$ & $40.30 \%$ & $100.00 \%$ \\
\hline & $\%$ within Sex & $100.00 \%$ & $100.00 \%$ & $100.00 \%$ & $100.00 \%$ & $100.00 \%$ & $100.00 \%$ \\
\hline
\end{tabular}

\subsection{Evaluation of gender differences in the consumption habits and knowledge about food fibres}

To evaluate gender differences and answer RQ3, the $t$ test for independent variables was used, being the results presented in Table 4. As for the existence of gender differences regarding Lebanese food habits, there are significant gender differences for the consumption of fruits, for the frequency of eating out and for the consumption of fast food.

Several studies highlight the need to consume adequate amount of fruits and vegetables, as a way to ingest the necessary requirements of macronutrients (such as protein, carbohydrates, fat, ect...) and micronutrients (vitamins and minerals), as well as bioactive compounds with health effects, like phenolic compounds present abundantly in the plant kingdom (López-González et al., 2021; Manjunath et al., 2021; Morze et al., 2020; Sosalagere et al., 2022).

According to Morse and Driskell (Morse \& Driskell, 2009), the explanation for a higher percentage of men reporting to eat at fast-food restaurants than women is because men believed that this type of restaurants constituted cheap alternative. On the other hand, for the women, it was very important the nutrition content of 
food, and therefore they eat at fast food restaurants less often (Morse \& Driskell, 2009). Hidaka et al. (Hidaka et al., 2018) concluded that fast food consumption was linked to higher levels of education in women, but the same was not verified in men.

Table 4. Results of T-test for gender differences regarding consumption habits

\begin{tabular}{lccccccc}
\hline & Sex & Mean & SD & F & Sig. (P) & T & DF \\
\hline Consuming fruit & Female & 3.03 & 1.34 & 5.670 & $\mathbf{0 . 0 1 8}$ & -0.016 & 206.094 \\
& Male & 3.03 & 1.48 & & & & \\
Consuming vegetables and salads & Female & 2.64 & 1.45 & 0.141 & 0.707 & -0.353 & 256 \\
& Male & 2.70 & 1.49 & & & -0.653 & 256 \\
Eating whole cereals & Female & 3.84 & 1.75 & 0.607 & 0.437 & -0.656 & 196.644 \\
& Male & 3.98 & 1.70 & & & \\
Eating out & Female & 3.42 & 0.95 & 7.397 & $\mathbf{0 . 0 0 7}$ & & \\
& Male & 3.51 & 1.11 & & & \\
Consuming fast food & Female & 3.71 & 0.94 & 11.655 & $\mathbf{0 . 0 0 1}$ & -0.385 & 181.131 \\
& Male & 3.77 & 1.23 & & & & \\
\hline
\end{tabular}

Furthermore, the authors used the six items in the scale for food knowledge to evaluate the reliability through Cronbach's alfa. The value showed a moderate internal reliability $(\alpha=0.642)$. Again, an independent t-test was conducted to find possible gender differences, whose results are reported in Table 5. The results showed significant differences at the level of $5 \%$ only for the last item, about the classification of fibre into soluble and insoluble. Ljubicic et al. (2017) investigated on a sample of Croatian participants, the influence of several variable on the level of knowledge about fibre and fibre consumption, namely variables age, gender, education and living environment. These differences can be used to produce targeted education campaigns to improve eating habits and, as a consequence, the general health status.

Table 5. Results of T-test for gender differences regarding knowledge

\begin{tabular}{|c|c|c|c|c|c|c|c|}
\hline & Sex & Mean & SD & $\mathbf{F}$ & Sig. (P) & $\mathbf{T}$ & DF \\
\hline \multirow{2}{*}{$\begin{array}{l}\text { Fibres are naturally present in vegetable } \\
\text { foods. }\end{array}$} & Female & 2.18 & 1.03 & 2.561 & 0.111 & -2.217 & 256 \\
\hline & Male & 2.48 & 1.11 & & & & \\
\hline \multirow{2}{*}{$\begin{array}{l}\text { Foods of animal origin have no fibres (unless } \\
\text { added). }\end{array}$} & Female & 3.16 & 1.06 & 1.046 & 0.307 & 2.351 & 256 \\
\hline & Male & 2.84 & 1.13 & & & & \\
\hline \multirow{2}{*}{$\begin{array}{l}\text { The average adult should eat } 25 \mathrm{~g} \text { of fibre per } \\
\text { day. }\end{array}$} & Female & 3.44 & 0.81 & 1.425 & 0.234 & 1.395 & 256 \\
\hline & Male & 3.29 & 0.94 & & & & \\
\hline \multirow{2}{*}{$\begin{array}{l}\text { Whole foods have less fibre than non-whole } \\
\text { foods. }\end{array}$} & Female & 2.78 & 1.20 & 0.044 & 0.834 & -0.625 & 256 \\
\hline & Male & 2.88 & 1.22 & & & & \\
\hline \multirow{2}{*}{$\begin{array}{l}\text { The unpeeled fruits have less fibre than } \\
\text { peeled ones. }\end{array}$} & Female & 2.55 & 1.28 & 0.003 & 0.959 & -0.630 & 256 \\
\hline & Male & 2.65 & 1.27 & & & & \\
\hline \multirow{2}{*}{$\begin{array}{l}\text { Dietary fibres are classified into soluble and } \\
\text { insoluble. }\end{array}$} & Female & 3.18 & 0.90 & 6.244 & 0.013 & -0.828 & 199.761 \\
\hline & Male & 3.28 & 1.04 & & & & \\
\hline
\end{tabular}

\subsection{Evaluation of age differences in the consumption habits and knowledge about food fibres}

Research question RQ4 was addressed with a similar methodology as for RQ3. Table 6 shows the results of t test for age differences regarding the consumption habits and Table 7 the results for $t$ test regarding the food knowledge differences between age classes X (over 35 years) and Y (between 18 and 35 years). A significant difference was found for vegetable and salad consumption according to age group. These results show, particularly, that younger people eat more vegetables and salads when compared with older people. These findings are indicative that younger Lebanese generations are practicing even healthier diets than their ancestors, which is aligned to the theories of difference in food consumption between generations $\mathrm{X}$ and Y. Costa et al. (2022) evaluated the differences in fruit and vegetable consumption across generations for a sample of Brazilian 


\section{INSIGHTS INTO REGIONAL DEVELOPMENT}

ISSN 2669-0195 (online) http://jssidoi.org/jesi/

2021 Volume 3 Number 4 (December)

http://doi.org/10.9770/IRD.2020.3.4(5)

participants, and found that younger generations consume less fruit than traditionalists, and that contrarily to traditionalists, generations X and Y showed lower vegetables consumption. Hidaka et al. (2018) reported that age was negatively correlated with fast food intake, in a study undertaken in the United States.

When the researchers tested the level of knowledge of the population under study about fiber and food constituents in regard to age groups, they noticed that for all questions, there were no differences relating to age except to their knowledge about fibers constituents in unpeeled fruits compared to peeled ones results presented in Table 7). For this case the $\mathrm{P}$ value was equal to 0.023 , lower than the significance limit established, meaning that there is a significant difference in the knowledge according to the age group, i.e. between younger and older generation related to fibers in fruit skins.

Although a nutritive diet rich in vitamins, minerals and bioactive substances is essential for a good health status, healthy eating is a complex process which is influenced by a combination of knowledge, skills, and decisionmaking capabilities, besides personal preference, availability, and affordability. All these dimensions are linked to the concept of food literacy (Deshpande et al., 2009; Hemmer et al., 2021).

Table 6. Results of T-test for gender differences regarding consumption habits

\begin{tabular}{|c|c|c|c|c|c|c|c|c|}
\hline & Age & $\mathbf{N}$ & Mean & SD & $\mathbf{F}$ & Sig. (P) & $\mathbf{T}$ & DF \\
\hline \multirow[t]{2}{*}{ Consuming fruit } & $>35$ years & 150 & 2.90 & 1.36 & 0.038 & 0.845 & -1.377 & 256 \\
\hline & $18-35$ years & 108 & 3.14 & 1.42 & & & & \\
\hline \multirow{2}{*}{$\begin{array}{l}\text { Consuming } \\
\text { vegetables and salads }\end{array}$} & $>35$ years & 150 & 2.53 & 1.32 & 14.491 & 0.000 & -1.394 & 253.338 \\
\hline & $18-35$ years & 108 & 2.78 & 1.58 & & & & \\
\hline \multirow[t]{2}{*}{ Eating whole cereals } & $>35$ years & 150 & 3.71 & 1.66 & 0.377 & 0.540 & -1.670 & 256 \\
\hline & $18-35$ years & 108 & 4.07 & 1.78 & & & & \\
\hline \multirow[t]{2}{*}{ Eating out } & $>35$ years & 150 & 3.47 & 0.94 & 1.891 & 0.170 & 0.157 & 256 \\
\hline & $18-35$ years & 108 & 3.45 & 1.09 & & & & \\
\hline \multirow[t]{2}{*}{ Consuming fast food } & $>35$ years & 150 & 3.90 & 1.04 & 1.160 & 0.283 & 2.320 & 256 \\
\hline & $18-35$ years & 108 & 3.59 & 1.08 & & & & \\
\hline
\end{tabular}

Table 7. Results of T-test for gender differences regarding knowledge

\begin{tabular}{|c|c|c|c|c|c|c|c|}
\hline & Age & Mean & SD & $\mathbf{F}$ & Sig. (P) & $\mathbf{T}$ & DF \\
\hline \multirow{2}{*}{$\begin{array}{l}\text { Fibres are naturally present in } \\
\text { vegetable foods. }\end{array}$} & $>35$ years & 2.37 & 1.07 & 0.440 & 0.508 & 0.991 & 256 \\
\hline & $18-35$ years & 2.24 & 1.07 & & & & \\
\hline \multirow{2}{*}{$\begin{array}{l}\text { Foods of animal origin have no } \\
\text { fibres (unless added). }\end{array}$} & $>35$ years & 3.00 & 1.16 & 1.250 & 0.265 & -0.434 & 256 \\
\hline & $18-35$ years & 3.06 & 1.05 & & & & \\
\hline \multirow{2}{*}{$\begin{array}{l}\text { The average adult should eat } 25 \mathrm{~g} \\
\text { of fibre per day. }\end{array}$} & $>35$ years & 3.35 & 0.89 & 0.032 & 0.858 & -0.589 & 256 \\
\hline & $18-35$ years & 3.41 & 0.85 & & & & \\
\hline \multirow{2}{*}{$\begin{array}{l}\text { Whole foods have less fibre than } \\
\text { non-whole foods. }\end{array}$} & > 35 years & 2.75 & 1.25 & 0.937 & 0.334 & -0.868 & 256 \\
\hline & 18-35 years & 2.88 & 1.17 & & & & \\
\hline \multirow{2}{*}{$\begin{array}{l}\text { The unpeeled fruits have less fibre } \\
\text { than peeled ones. }\end{array}$} & > 35 years & 2.61 & 1.35 & 5.202 & 0.023 & 0.240 & 247.104 \\
\hline & $18-35$ years & 2.57 & 1.20 & & & & \\
\hline \multirow{2}{*}{$\begin{array}{l}\text { Dietary fibres are classified into } \\
\text { soluble and insoluble. }\end{array}$} & $>35$ years & 3.23 & 1.02 & 3.372 & 0.067 & 0.141 & 256 \\
\hline & $18-35$ years & 3.21 & 0.90 & & & & \\
\hline
\end{tabular}

\section{Discussion}

In the past decades, there has been a trend to follow dietary patterns which do not comply with the recommended intake of macronutrients, micronutrients or bioactive compounds present in food, and these inadequate diets have proven to result in severe diet-related non-communicable diseases such as type 2 diabetes, cardiovascular disorders, hypertension and some forms of cancer (Verain et al., 2022). Diets too dense in fat, and especially trans saturated fat has been reported to contribute to a number of diseases, like hypertension, obesity and diabetes (Gayed et al., 2021; Otagiri et al., 2021). However, excessive fat has also been proven to affect brain diseases, 


\section{INSIGHTS INTO REGIONAL DEVELOPMENT}

ISSN 2669-0195 (online) http://jssidoi.org/jesi/

2021 Volume 3 Number 4 (December)

http://doi.org/10.9770/IRD.2020.3.4(5)

especially those related with ageing, such as Alzheimer's disease (Sarroca et al., 2021). Diets with a high level of protein intake is associated with kidney failure (Kim et al., 2021). The excessive intake of salt has been reported as contributing to the onset of many heart related pathologies, such as coronary heart disease, stroke, myocardial infarction, cardiovascular disease or hypertension (He et al., 2020; Igreja et al., 2019; Ikehara et al., 2012). Still, these studies must encompass that not all patients respond in the same way to salt reduction strategies, and the debate is ongoing (Khan et al., 2020; Messerli et al., 2018). Collins et al. (Collins et al., 2014) conducted a study to evaluate the cost-effectiveness of four different population health policies to reduce dietary salt intake in the United kingdom as a way to prevent coronary heart disease, and they found that all the four policies aimed at reducing the dietary intake of salt could increase the life expectancy while reducing health care expenditure on coronary heart disease. A similar study by Shoaibi et al. (2013) also analysed three salt-reduction interventions from societal perspective in Palestinian territory and found that all evaluated policies resulted in a reduction in salt intake, with an impact on heart health. The burden associated with diseases provoked by inappropriate dietary patterns is a problem worldwide nowadays and governments and policy makers try to implement strategies to improve people's diets with a gain in many aspects of human health (Bhattarai et al., 2020; Lui et al., 2021; Wen et al., 2022). Foods such as fruits, vegetables or salads, and whole cereals are seen as potent allies to improve human health and reduce the risk of disease owing to their beneficial components (Newberry \& Lynch, 2021; L. Sun et al., 2021; van der Heijden et al., 2021; Visvanathan \& Williamson, 2021). They include vitamins, minerals and bioactive substances such as phenolic compounds with antioxidant activity, which help the human body to fight the harmful effects of oxidative stress (Alì et al., 2021; Jiang et al., 2021; Singh et al., 2020). Dietary fibre, present in this type of foods is particularly important to the health of the gastrointestinal system and certain types of cancer (Gill et al., 2018; Johnson, 2005; Mao et al., 2021; McRae, 2018; Tang et al., 2013; Tomas et al., 2020; Wunjuntuk et al., 2022; Xu et al., 2018). Hence incentive the consumption of fibre rich foods is a way to improve the health of the general population. This wok showed that the Lebanese consume moderate amounts of fruits and vegetables, which might be linked to the influence of the Mediterranean dietary patterns. Nevertheless, the consumption of whole cereals is lower than the amounts recommended. This can be associated with the modernization of eating habits, namely eating out and consuming fast-food frequently, as influences by westernization (Hussain et al., 2019; Leech et al., 2017; Schaalan et al., 2009). The work by Guiné et al. (2020) evaluated the consumption of fruits, vegetables and whole cereals in Portugal, Croatia, Latvia, Romania and Hungary, and it was observed that these foods were also consumed in amounts lower than recommended in all countries. According to Van der Heijden et al. (2021) healthy eating is variable according to the socioeconomic position, and therefore countries with lower average economic power may face more difficulties in implementing effective strategies to promote healthier eating habits. Dhakal and khadka (2021) investigated in what extent the household food budget influences diet quality and weight-related health outcomes in the United States. They observed that families with lower income households, who spent a larger part of their food budget at convenience stores and fast-food restaurants are those practicing lower quality diets, which in turn are associated with a higher risk of obesity. They believe that their work may bring to light possible intervention strategies to address obesity. Penne and Goedemé (2021) reported that in 16 out of 24 EU countries, at least $10 \%$ of people experience some kind of financial constraints that limit them to eat healthily. Hence, they suggest that policies should increase their focus on ensuring adequate incomes as a way to improve dietary habits and therefore diminish non-communicable diseases.

Apart from the food consumption habits, one other aspect investigated in this research was the level of knowledge about dietary fibre. The knowledge is a powerful tool to help citizens in general, and food consumers in particular, to make informed choices. Velardo (2015) discusses the concepts of health literacy, nutrition literacy, and food literacy, and how they interrelate proposing a model based on health literacy as a way to facilitate healthy food relationships. Many factors can be pointed out that contribute to poor dietary practices, but they analysis is complex and requires an interdisciplinary approach that includes the social context. Rodriguez (2011) refers that it is important to teach skills to manage health, i.e., give the public the tools to increase their levels of knowledge and take better care of their health status. Public health requires cross-sector collaboration as well as policy 


\section{INSIGHTS INTO REGIONAL DEVELOPMENT}

ISSN 2669-0195 (online) http://jssidoi.org/jesi/

2021 Volume 3 Number 4 (December)

http://doi.org/10.9770/IRD.2020.3.4(5)

actions that directly affect the social determinants of health. Food literacy is a motor to the preparation of nutritious food aimed at a better health (Alexander, 2020; DeSalvo et al., 2016). Shahavandi et al. (2021) reported that higher health literacy levels were associated with better healthy eating patterns in Iranian adults. Palumbo et al. (2019) reported low food literacy among Italians and that inappropriate food literacy contributes to worsening individual health status. Truman and Elliot (2019) published a review that focuses on the barriers to food literacy proficiency evaluating the relationships between food knowledge, attitudes, and behaviors. Their ultimate objective was the development of a model that might be available for researchers, educators, and nutrition professionals to implement effective interventions capable of effectively changing food-related attitudes. The results of the present research showed that the Lebanese have a low knowledge about some aspects related with dietary fibre, like for example, the recommended dosages or the natural sources of fibre. Guiné et al. (2017) reported a good general level of knowledge about the benefits of dietary fibre for the human health on a sample of more than 6 thousand participants from 10 countries. However, for the same sample, the level of knowledge regarding the sources of dietary fibre or recommended dosages was also low, particularly in Egypt, which is a country very close to Lebanon, and with eventually some similarities in economic terms (Guiné et al., 2016). These studies reveal that there is still a long way to go with the goal of improving food literacy as a way to promote better food choices that envisage promotion of health status and reduce the economic burden of foodrelated diseases.

\section{Conclusions}

The importance of this work resided in the highlight of the food knowledge and habits in Lebanon, specifically, in a country defined by a multi-ethnical diversity and religiosity and where food habits were mainly related to social behaviour, therefore this study adds more knowledge about these people's food behaviour and add more data to specific types of food attitude.

Regarding the food habits, we concluded that the Lebanese consume fruits and vegetables on a daily basis, but the consumption of whole grains is low. The frequency of eating outside form home is high and the consumption of fast food is also very high. In what concerns the knowledge about dietary fibre, it was fund that the Lebanese still lack information about this topic, and therefore this is a problem that the Lebanese authorities should address as a way to improve the health of the population, given the many health benefits of a diet rich in dietary fibre. Therefore, the main highlights are on the low level of knowledge, and the importance to design better strategies to improve the literacy of the Lebanese as a way to incentive them to consume healthier foods, namely in the categories of fruits, vegetables and whole grains, given their proven roles as promoters of health. The evaluation of gender or age differences can bring light as to how targeting each intervention and policy strategy directly to be more effective according to gender or age groups, instead of directing campaigns to the whole population that might not be as effective.

The social and economic context of Lebanon makes it imperative to implement adequate instruments to address the health care systems and just import solutions from other countries' experiences might not be an adequate choice. For this reason, the present work may present an opportunity to build strong campaigns to better inform the Lebanese and help them make more adequate food choices. 


\section{INSIGHTS INTO REGIONAL DEVELOPMENT}

ISSN 2669-0195 (online) http://jssidoi.org/jesi/

2021 Volume 3 Number 4 (December)

http://doi.org/10.9770/IRD.2020.3.4(5)

\section{References}

Alexander, G. K. (2020). Supporting food literacy among children and adolescents: Undergraduate students apply public health nursing principles in clinical practice. Journal of Professional Nursing, 36(6), 616-624. https://doi.org/10.1016/j.profnurs.2020.08.018

Alì, S., Davinelli, S., Accardi, G., Aiello, A., Caruso, C., Duro, G., Ligotti, M. E., Pojero, F., Scapagnini, G., \& Candore, G. (2021). Healthy ageing and Mediterranean diet: A focus on hormetic phytochemicals. Mechanisms of Ageing and Development, 111592. https://doi.org/10.1016/j.mad.2021.111592

Azevedo Perry, E., Thomas, H., Samra, H. R., Edmonstone, S., Davidson, L., Faulkner, A., Petermann, L., Manafò, E., \& Kirkpatrick, S. I. (2017). Identifying attributes of food literacy: A scoping review. Public Health Nutrition, 20(13), 2406-2415. https://doi.org/10.1017/S1368980017001276

Bandura, A. (1999). Social Cognitive Theory: An Agentic Perspective. Asian Journal of Social Psychology, $2(1)$, $21-41$. https://doi.org/10.1111/1467-839X.00024

Bhattarai, S., Aryal, A., Pyakurel, M., Bajracharya, S., Baral, P., Citrin, D., Cox, H., Dhimal, M., Fitzpatrick, A., Jha, A. K., Jha, N., Karmacharya, B. M., Koju, R., Maharjan, R., Oli, N., Pyakurel, P., Sapkota, B. P., Shrestha, R., Shrestha, S., ... Shrestha, A. (2020). Cardiovascular disease trends in Nepal - An analysis of global burden of disease data 2017. IJC Heart \& Vasculature, $30,100602$. https://doi.org/10.1016/j.ijcha.2020.100602

Boustani, N. M., \& Guiné, R. P. F. (2020). Food choice motivations and perception of a healthy diet in a developing Mediterranean country. Open Agriculture, 5(1), 485-495. https://doi.org/10.1515/opag-2020-0048

Cochran, W. G. (1977). Sampling Techniques (3rd Edition). John Wiley \& Sons. https://www.wiley.com/enus/Sampling+Techniques\%2C+3rd+Edition-p-9780471162407

Collins, M., Mason, H., O’Flaherty, M., Guzman-Castillo, M., Critchley, J., \& Capewell, S. (2014). An Economic Evaluation of Salt Reduction Policies to Reduce Coronary Heart Disease in England: A Policy Modeling Study. Value in Health, 17(5), 517-524. https://doi.org/10.1016/j.jval.2014.03.1722

Costa, G. A. M., Lopes, M. S., \& Lopes, A. C. S. (2022). Fruit and vegetable consumption across generations of primary Brazilian care users. Nutrition, 93, 111435. https://doi.org/10.1016/j.nut.2021.111435

Davy, S. R., Benes, B. A., \& Driskell, J. A. (2006). Sex differences in dieting trends, eating habits, and nutrition beliefs of a group of midwestern college students. Journal of the American Dietetic Association, 106(10), 1673-1677. https://doi.org/10.1016/j.jada.2006.07.017

DeSalvo, K. B., O’Carroll, P. W., Koo, D., Auerbach, J. M., \& Monroe, J. A. (2016). Public Health 3.0: Time for an Upgrade. American Journal of Public Health, 106(4), 621-622. https://doi.org/10.2105/AJPH.2016.303063

Deshpande, S., Basil, M. D., \& Basil, D. Z. (2009). Factors Influencing Healthy Eating Habits Among College Students: An Application of the Health Belief Model. Health Marketing Quarterly, 26(2), 145-164. https://doi.org/10.1080/07359680802619834

Dhakal, C. K., \& Khadka, S. (2021). Heterogeneities in Consumer Diet Quality and Health Outcomes of Consumers by Store Choice and Income. Nutrients, 13(4), 1046. https://doi.org/10.3390/nu13041046

Digital in Lebanon: All the Statistics You Need in 2021. (sem data). DataReportal - Global Digital Insights. Obtido 26 de Outubro de 2021 , de https://datareportal.com/reports/digital-2021-lebanon

Ferreira, M., Guiné, R. P. F., Duarte, J., Correia, P., Leal, M., Baric, I. C., Komes, D., Saric, M. M., Tarcea, M., Fazakas, Z., Jovanoska, D., Vanevski, D., Vittadini, E., Pellegrini, N., Szücs, V., Harangozo, J., EL-Kenawy, A., EL-Shenawy, O., Yalcin, E., ... Straumite, E. (2016). Sources of Information about Dietary Fibre: A Cross-Country Survey. The European Proceedings of Social and Behavioural Sciences EpSBS, XVI, 7-17. https://doi.org/10.15405/epsbs.2016.11.2

Garcia, S., Valencia, C., \& Amaro, H. (2021). Cognitive Factors Associated with Frequency of Eating Out and Eating Takeout among Latinas. Journal of the Academy of Nutrition and Dietetics, 121(3), 520-528. https://doi.org/10.1016/j.jand.2020.08.089 


\section{INSIGHTS INTO REGIONAL DEVELOPMENT}

ISSN 2669-0195 (online) http://jssidoi.org/jesi/

2021 Volume 3 Number 4 (December)

http://doi.org/10.9770/IRD.2020.3.4(5)

Gayed, E. M. A. E., Zewain, S. K. E. D., Ragheb, A., \& ElNaidany, S. S. (2021). Fat mass and obesity-associated gene expression and disease severity in type 2 diabetes mellitus. Steroids, 174, 108897. https://doi.org/10.1016/j.steroids.2021.108897

Georgescu, I. M., Rus, V. A., Tarcea, M., Ruta, F., Fazakas, Z., Guine, R., Serban, C., Iacob, I., \& Frigy, A. (2019). Population preferences for sources that offers information about dietary fibres health effects-An international cross-sectional survey. JPMA. The Journal of the Pakistan Medical Association, 69(7), 985-990.

Gill, S., Chater, P. I., Wilcox, M. D., Pearson, J. P., \& Brownlee, I. A. (2018). The impact of dietary fibres on the physiological processes of the large intestine. Bioactive Carbohydrates and Dietary Fibre, 16, 62-74. https://doi.org/10.1016/j.bcdf.2018.06.001

Guiné, R., Duarte, J., Ferreira, M., Correia, P., Leal, M., Rumbak, I., Baric, I., Komes, D., Satalic, Z., Saric, M. M., Tarcea, M., Fazakas, Z., Jovanoska, D., Vanevski, D., Vittadini, E., Pellegrini, N., Szucs, V., Harangozó, J., EL-Kenawy, A., ... Straumite, E. (2017). Benefits of dietary fibre to human health: Study from a multi-country platform. Nutrition \& Food Science, 47(5), 688-699. https://doi.org/10.1108/NFS-11-2016-0165

Guiné, R., Ferreira, M., Correia, P., Duarte, J., Leal, M., Rumbak, I., Barić, I. C., Komes, D., Satalić, Z., Sarić, M. M., Tarcea, M., Fazakas, Z., Jovanoska, D., Vanevski, D., Vittadini, E., Pellegrini, N., Szücs, V., Harangozó, J., El-Kenawy, A., ... Straumite, E. (2016). Knowledge about dietary fibre: A fibre study framework. International Journal of Food Sciences and Nutrition, 67(6), 707-714. https://doi.org/10.1080/09637486.2016.1191443

Guiné, R. P. F., Florença, S. G., Barroca, M. J., \& Anjos, O. (2020). The Link between the Consumer and the Innovations in Food Product Development. Foods, 9(9), 1317. https://doi.org/10.3390/foods9091317

Guiné, R. P. F., Florença, S. G., Leal, M., Rumbak, I., Barić, I., Komes, D., Satalić, Z., Sarić, M., Tarcea, M., Fazakas, Z., Szücs, V., Harangozó, J., Klava, D., \& Straumite, E. (2020). Consumption of fibre rich foods: Comparative study in different countries. Croatian Journal of Food Science and Technology, 12(1), 67-76. https://doi.org/10.17508/CJFST.2020.12.1.09

Guiné, R. P. F., Florença, S. G., Villalobos Moya, K., \& Anjos, O. (2020). Edible Flowers, Old Tradition or New Gastronomic Trend: A First Look at Consumption in Portugal versus Costa Rica. Foods, 9(8), 977. https://doi.org/10.3390/foods9080977

Hammond, R. K., Velikova, N., \& Dodd, T. H. (2013). Effects of Processing Styles on the Preference of Restaurant Menu Type: How Do Millennials Compare to Other Segments? Journal of Foodservice Business Research, 16(1), 20-39. https://doi.org/10.1080/15378020.2012.734237

He, F. J., Tan, M., Ma, Y., \& MacGregor, G. A. (2020). Salt Reduction to Prevent Hypertension and Cardiovascular Disease: JACC Stateof-the-Art Review. Journal of the American College of Cardiology, 75(6), 632-647. https://doi.org/10.1016/j.jacc.2019.11.055

Hemmer, A., Hitchcock, K., Lim, Y. S., Butsch Kovacic, M., \& Lee, S.-Y. (2021). Development of Food Literacy Assessment Tool Targeting Low-Income Adults. Journal of Nutrition Education and Behavior. https://doi.org/10.1016/j.jneb.2021.05.007

Hidaka, B. H., Hester, C. M., Bridges, K. M., Daley, C. M., \& Greiner, K. A. (2018). Fast food consumption is associated with higher education in women, but not men, among older adults in urban safety-net clinics: A cross-sectional survey. Preventive Medicine Reports, 12, 148-151. https://doi.org/10.1016/j.pmedr.2018.09.005

Hussain, Y., Jain, S. K., \& Samaiya, P. K. (2019). Short-term westernized (HFFD) diet fed in adolescent rats: Effect on glucose homeostasis, hippocampal insulin signaling, apoptosis and related cognitive and recognition memory function. Behavioural Brain Research, 361, 113-121. https://doi.org/10.1016/j.bbr.2018.12.042

Igreja, B., Pires, N. M., Wright, L. C., \& Soares-da-Silva, P. (2019). Effects of zamicastat treatment in a genetic model of salt-sensitive hypertension and heart failure. European Journal of Pharmacology, 842, 125-132. https://doi.org/10.1016/j.ejphar.2018.10.030

Ikehara, S., Iso, H., Date, C., Kikuchi, S., Watanabe, Y., Inaba, Y., \& Tamakoshi, A. (2012). Salt preference and mortality from stroke and coronary heart disease for Japanese men and women: The JACC study. Preventive Medicine, 54(1), 32-37. https://doi.org/10.1016/j.ypmed.2011.10.013

Jang, Y. J., Kim, W. G., \& Bonn, M. A. (2011). Generation Y consumers' selection attributes and behavioral intentions concerning green restaurants. International Journal of Hospitality Management, 30(4), 803-811. https://doi.org/10.1016/j.ijhm.2010.12.012 


\section{INSIGHTS INTO REGIONAL DEVELOPMENT}

ISSN 2669-0195 (online) http://jssidoi.org/jesi/

2021 Volume 3 Number 4 (December)

http://doi.org/10.9770/IRD.2020.3.4(5)

Jiang, Y., Fang, Z., Leonard, W., \& Zhang, P. (2021). Phenolic compounds in Lycium berry: Composition, health benefits and industrial applications. Journal of Functional Foods, 77, 104340. https://doi.org/10.1016/j.jff.2020.104340

Johnson, I. T. (2005). The biological effects of dietary fibre in the samll intestine. Em D. A. T. Southgate, K. Waldron, I. T. Johnson, \& G. R. Fenwick (Eds.), Dietary Fibre (pp. 151-163). Woodhead Publishing. https://doi.org/10.1533/9781845698195.4.151

Khan, M. S., Jones, D. W., \& Butler, J. (2020). Salt, No Salt, or Less Salt for Patients With Heart Failure? The American Journal of Medicine, 133(1), 32-38. https://doi.org/10.1016/j.amjmed.2019.07.034

Kim, H., Lee, H., Kwon, S. H., Jeon, J. S., Noh, H., Han, D. C., \& Kim, H. (2021). Relationship between carbohydrate-to-fat intake ratio and the development of chronic kidney disease: A community-based prospective cohort study. Clinical Nutrition, 40(10), 5346-5354. https://doi.org/10.1016/j.clnu.2021.09.001

Kolanowski, W., Trafialek, J., Drosinos, E. H., \& Tzamalis, P. (2020). Polish and Greek young adults' experience of low quality meals when eating out. Food Control, 109, 106901. https://doi.org/10.1016/j.foodcont.2019.106901

Kolasa, K., Peery, A., Harris, N., \& Shovelin, K. (2001). Food Literacy Partners Program: A Strategy To Increase Community Food Literacy. Topics in Clinical Nutrition, 16(4), 77-79. https://doi.org/10.1097/00008486-200116040-00002

Lee, C., \& Pena-y-Lillo, M. (2021). A communication inequalities approach to disparities in fruit and vegetable consumption: Findings from a national survey with U.S. adults. Patient Education and Counseling. https://doi.org/10.1016/j.pec.2021.06.005

Leech, R. M., Timperio, A., Livingstone, K. M., Worsley, A., \& McNaughton, S. A. (2017). Temporal eating patterns: Associations with nutrient intakes, diet quality, and measures of adiposity. The American Journal of Clinical Nutrition, 106(4), 1121-1130. https://doi.org/10.3945/ajcn.117.156588

Levin, J., \& Fox, J. A. (2004). Estatística para Ciências Humanas (9ª ed.). Pearson.

Levine, D. M., Stephan, D. F., Krehbiel, T. C., \& Berenson, M. L. (2008). Estatistica Teoria E Aplicacoes Usando O Microsoft Excel Em Portugues (5 ed.). LTC.

Ljubicic, M., Saric, M. M., Rumbak, I., Baric, I. C., Komes, D., Satalic, Z., \& Guiné, R. P. F. (2017). Knowledge about dietary fibre and its health benefits: A cross-sectional survey of 2536 residents from across Croatia. Medical Hypotheses, 105, $25-31$. https://doi.org/10.1016/j.mehy.2017.06.019

López-González, L., Becerra-Tomás, N., Babio, N., Martínez-González, M. Á., Díaz-López, A., Corella, D., Goday, A., Romaguera, D., Vioque, J., Alonso-Gómez, Á. M., Wärnberg, J., Martínez, J. A., Serra-Majem, L., Estruch, R., Tinahones, F., Lapetra, J., Pintó, X., Tur, J. A., López-Miranda, J., ... Salas-Salvadó, J. (2021). Variety in fruits and vegetables, diet quality and lifestyle in an older adult mediterranean population. Clinical Nutrition, 40(4), 1510-1518. https://doi.org/10.1016/j.clnu.2021.02.024

Lui, M., Safiri, S., Mereke, A., Davletov, K., Mebonia, N., Myrkassymova, A., Aripov, T., Mirrakhimov, E., Aghayan, S. A., Gamkrelidze, A., Naghavi, M., Kopec, J. A., \& Sarrafzadegan, N. (2021). Burden of Ischemic Heart Disease in Central Asian Countries, 1990-2017. IJC Heart \& Vasculature, 33, 100726. https://doi.org/10.1016/j.ijcha.2021.100726

Manjunath, C., Jenkins, S. M., Phelan, S., Breitkopf, C. R., Hayes, S. N., Cooper, L. A., Patten, C. A., \& Brewer, L. C. (2021). Association of body image dissatisfaction, behavioral responses for healthy eating, and cardiovascular health in African-American women with overweight or obesity: A preliminary study. American Journal of Preventive Cardiology, 8, 100254. https://doi.org/10.1016/j.ajpc.2021.100254

Mao, T., Huang, F., Zhu, X., Wei, D., \& Chen, L. (2021). Effects of dietary fiber on glycemic control and insulin sensitivity in patients with type 2 diabetes: A systematic review and meta-analysis. Journal of Functional Foods, 82, 104500. https://doi.org/10.1016/j.jff.2021.104500

McRae, M. P. (2018). The Benefits of Dietary Fiber Intake on Reducing the Risk of Cancer: An Umbrella Review of Meta-analyses. Journal of Chiropractic Medicine, 17(2), 90-96. https://doi.org/10.1016/j.jcm.2017.12.001 


\section{INSIGHTS INTO REGIONAL DEVELOPMENT}

ISSN 2669-0195 (online) http://jssidoi.org/jesi/

2021 Volume 3 Number 4 (December)

http://doi.org/10.9770/IRD.2020.3.4(5)

Messerli, F. H., Hofstetter, L., \& Bangalore, S. (2018). Salt and heart disease: A second round of "bad science"? The Lancet, 392(10146), 456-458. https://doi.org/10.1016/S0140-6736(18)31724-0

Morse, K. L., \& Driskell, J. A. (2009). Observed sex differences in fast-food consumption and nutrition self-assessments and beliefs of college students. Nutrition Research, 29(3), 173-179. https://doi.org/10.1016/j.nutres.2009.02.004

Morze, J., Danielewicz, A., Hoffmann, G., \& Schwingshackl, L. (2020). Diet Quality as Assessed by the Healthy Eating Index, Alternate Healthy Eating Index, Dietary Approaches to Stop Hypertension Score, and Health Outcomes: A Second Update of a Systematic Review and Meta-Analysis of Cohort Studies. Journal of the Academy of Nutrition and Dietetics, 120(12), 1998-2031.e15. https://doi.org/10.1016/j.jand.2020.08.076

Namin, A., Ratchford, B. T., Saint Clair, J. K., Bui, M. (Myla), \& Hamilton, M. L. (2020). Dine-in or take-out: Modeling millennials' cooking motivation and choice. Journal of Retailing and Consumer Services, 53, 101981. https://doi.org/10.1016/j.jretconser.2019.101981

National Academies of Sciences, Engineering, and Medicine. (2016). Food Literacy: How Do Communications and Marketing Impact Consumer Knowledge, Skills, and Behavior? Workshop Summary (L. Pray, Ed.). The National Academies Press. https://doi.org/10.17226/21897

Newberry, C., \& Lynch, K. (2021). Using Diet to Treat Diseases of Esophagus: Back to the Basics. Gastroenterology Clinics of North America. https://doi.org/10.1016/j.gtc.2021.08.008

Nyheim, P., Xu, S., Zhang, L., \& Mattila, A. S. (2015). Predictors of avoidance towards personalization of restaurant smartphone advertising: A study from the Millennials' perspective. Journal of Hospitality and Tourism Technology, 6(2), 145-159. https://doi.org/10.1108/JHTT-07-2014-0026

Okumus, B., Dedeoğlu, B. B., \& Shi, F. (2021). Gender and generation as antecedents of food neophobia and food neophilia. Tourism Management Perspectives, 37, 100773. https://doi.org/10.1016/j.tmp.2020.100773

Otagiri, K., Machida, K., Itagaki, T., Takeuchi, T., Tsujinaka, Y., Yui, H., Nakamura, C., Sakai, T., Kato, T., Saigusa, T., Ebisawa, S., Motoki, H., Kuwahara, K., \& Kitabayashi, H. (2021). Predictive Value of Abdominal Fat Distribution on Coronary Artery Disease Severity Stratified by Computed Tomography-Derived SYNTAX Score. The American Journal of Cardiology, 150, 32-39. https://doi.org/10.1016/j.amjcard.2021.03.035

Palumbo, R., Adinolfi, P., Annarumma, C., Catinello, G., Tonelli, M., Troiano, E., Vezzosi, S., \& Manna, R. (2019). Unravelling the food literacy puzzle: Evidence from Italy. Food Policy, 83, 104-115. https://doi.org/10.1016/j.foodpol.2018.12.004

Penne, T., \& Goedemé, T. (2021). Can low-income households afford a healthy diet? Insufficient income as a driver of food insecurity in Europe. Food Policy, 99, 101978. https://doi.org/10.1016/j.foodpol.2020.101978

Rodriguez, J. C. (2011). Serving the Public: Health Literacy and Food Deserts. Journal of the American Dietetic Association, $111(1), 14$. https://doi.org/10.1016/j.jada.2010.11.009

Roseman, M. G., Joung, H.-W., Choi, E.-K. C., \& Kim, H.-S. (2017). The effects of restaurant nutrition menu labelling on college students' healthy eating behaviours. Public Health Nutrition, 20(5), 797-804. https://doi.org/10.1017/S1368980016002871

Rosenbaum, J., Derby, E., \& Dutta, K. (2015). Understanding Consumer Preference and Willingness to Pay for Improved Cookstoves in Bangladesh. Journal of Health Communication, 20(sup1), 20-27. https://doi.org/10.1080/10810730.2014.989345

Sarroca, S., Gatius, A., Rodríguez-Farré, E., Vilchez, D., Pallàs, M., Griñán-Ferré, C., Sanfeliu, C., \& Corpas, R. (2021). Resveratrol confers neuroprotection against high-fat diet in a mouse model of Alzheimer's disease via modulation of proteolytic mechanisms. The Journal of Nutritional Biochemistry, 89, 108569. https://doi.org/10.1016/j.jnutbio.2020.108569

Schaalan, M., El-Abhar, H. S., Barakat, M., \& El-Denshary, E. S. (2009). Westernized-like-diet-fed rats: Effect on glucose homeostasis, lipid profile, and adipocyte hormones and their modulation by rosiglitazone and glimepiride. Journal of Diabetes and Its Complications, 23(3), 199-208. https://doi.org/10.1016/j.jdiacomp.2008.02.003 


\section{INSIGHTS INTO REGIONAL DEVELOPMENT}

ISSN 2669-0195 (online) http://jssidoi.org/jesi/

2021 Volume 3 Number 4 (December)

http://doi.org/10.9770/IRD.2020.3.4(5)

Shahavandi, M., Ghorbaninejad, P., Mohammadpour, S., Djafari, F., Shahinfar, H., Sheikhhossein, F., Djafarian, K., \& Shab-Bidar, S. (2021). Higher health literacy score is associated with better healthy eating index in Iranian adults. Nutrition, 90, 111262. https://doi.org/10.1016/j.nut.2021.111262

Shoaibi, A., Ghandour, R., Khatib, R., Mason, H., O’Flaherty, M., Capewell, S., \& Husseini, A. (2013). Salt reduction as a populationbased intervention for the prevention of coronary heart diseases: An economic assessment. The Lancet, 382 , S33. https://doi.org/10.1016/S0140-6736(13)62605-7

Singh, B., Singh, J. P., Kaur, A., \& Singh, N. (2020). Phenolic composition, antioxidant potential and health benefits of citrus peel. Food Research International, 132, 109114. https://doi.org/10.1016/j.foodres.2020.109114

Sosalagere, C., Adesegun Kehinde, B., \& Sharma, P. (2022). Isolation and functionalities of bioactive peptides from fruits and vegetables: A reviews. Food Chemistry, 366, 130494. https://doi.org/10.1016/j.foodchem.2021.130494

Sun, L., Liang, X., Wang, Y., Zhu, S., Ou, Q., Xu, H., Li, F., Tan, X., Lai, Z., Pu, L., Chen, X., Wei, J., Wu, F., Zhu, H., \& Wang, L. (2021). Fruit consumption and multiple health outcomes: An umbrella review. Trends in Food Science \& Technology. https://doi.org/10.1016/j.tifs.2021.09.023

Sun, Y.-H. C. (2008). Health concern, food choice motives, and attitudes toward healthy eating: The mediating role of food choice motives. Appetite, 51(1), 42-49. https://doi.org/10.1016/j.appet.2007.11.004

Tang, L., Xu, F., Zhang, T., Lei, J., Binns, C. W., \& Lee, A. H. (2013). Dietary fibre intake associated with reduced risk of oesophageal cancer in Xinjiang, China. Cancer Epidemiology, 37(6), 893-896. https://doi.org/10.1016/j.canep.2013.08.012

Tomas, M., Rocchetti, G., Ghisoni, S., Giuberti, G., Capanoglu, E., \& Lucini, L. (2020). Effect of different soluble dietary fibres on the phenolic profile of blackberry puree subjected to in vitro gastrointestinal digestion and large intestine fermentation. Food Research International, 130, 108954. https://doi.org/10.1016/j.foodres.2019.108954

Triola, M. F., \& Flores, V. R. L. F. (2017). Instrodução àEstatística (12a ed.). LTC.

Truman, E., \& Elliott, C. (2019). Barriers to Food Literacy: A Conceptual Model to Explore Factors Inhibiting Proficiency. Journal of Nutrition Education and Behavior, 51(1), 107-111. https://doi.org/10.1016/j.jneb.2018.08.008

Truman, E., Lane, D., \& Elliott, C. (2017). Defining food literacy: A scoping review. Appetite, 116, 365-371. https://doi.org/10.1016/j.appet.2017.05.007

van der Heijden, A., te Molder, H., Jager, G., \& Mulder, B. C. (2021). Healthy eating beliefs and the meaning of food in populations with a low socioeconomic position: A scoping review. Appetite, 161, 105135. https://doi.org/10.1016/j.appet.2021.105135

Velardo, S. (2015). The Nuances of Health Literacy, Nutrition Literacy, and Food Literacy. Journal of Nutrition Education and Behavior, 47(4), 385-389.e1. https://doi.org/10.1016/j.jneb.2015.04.328

Verain, M. C. D., Bouwman, E. P., Galama, J., \& Reinders, M. J. (2022). Healthy eating strategies: Individually different or contextdependent? Appetite, 168, 105759. https://doi.org/10.1016/j.appet.2021.105759

Visvanathan, R., \& Williamson, G. (2021). Effect of citrus fruit and juice consumption on risk of developing type 2 diabetes: Evidence on polyphenols from epidemiological and intervention studies. Trends in Food Science \& Technology, 115, 133-146. https://doi.org/10.1016/j.tifs.2021.06.038

Wardle, J., Haase, A. M., Steptoe, A., Nillapun, M., Jonwutiwes, K., \& Bellisle, F. (2004). Gender differences in food choice: The contribution of health beliefs and dieting. Annals of Behavioral Medicine: A Publication of the Society of Behavioral Medicine, 27(2), 107116. https://doi.org/10.1207/s15324796abm2702_5

Wen, J., Deng, P., Fu, Q., \& Chang, C.-P. (2022). Does health innovation relieve disease burden? The comprehensive evidence. Technological Forecasting and Social Change, 174, 121202. https://doi.org/10.1016/j.techfore.2021.121202 


\section{INSIGHTS INTO REGIONAL DEVELOPMENT}

ISSN 2669-0195 (online) http://jssidoi.org/jesi/

2021 Volume 3 Number 4 (December)

http://doi.org/10.9770/IRD.2020.3.4(5)

Wijayaratne, S. P., Reid, M., Westberg, K., Worsley, A., \& Mavondo, F. (2018). Food literacy, healthy eating barriers and household diet. European Journal of Marketing, 52(12), 2449-2477. https://doi.org/10.1108/EJM-10-2017-0760

Wunjuntuk, K., Ahmad, M., Techakriengkrai, T., Chunhom, R., Jaraspermsuk, E., Chaisri, A., Kiwwongngam, R., Wuttimongkolkul, S., \& Charoenkiatkul, S. (2022). Proximate composition, dietary fibre, beta-glucan content, and inhibition of key enzymes linked to diabetes and obesity in cultivated and wild mushrooms. Journal of Food Composition and Analysis, 105, 104226. https://doi.org/10.1016/j.jfca.2021.104226

Xu, H., Ding, Y., Xin, X., Wang, W., \& Zhang, D. (2018). Dietary fiber intake is associated with a reduced risk of ovarian cancer: A doseresponse meta-analysis. Nutrition Research, 57, 1-11. https://doi.org/10.1016/j.nutres.2018.04.011

Yahia, N., Achkar, A., Abdallah, A., \& Rizk, S. (2008). Eating habits and obesity among Lebanese university students. Nutrition Journal, 7(1), 32. https://doi.org/10.1186/1475-2891-7-32

Yoon, B., \& Chung, Y. (2018). Consumer Attitude and Visit Intention toward Food-Trucks: Targeting Millennials. Journal of Foodservice Business Research, 21(2), 187-199. https://doi.org/10.1080/15378020.2017.1368807

\section{Acknowledgements}

This work was an extension of the project PROJ/CI\&DETS/2014/0001 form CI\&DETS Research Centre at the Polytechnic Institute of Viseu. The authors acknowledge financial support from the Portuguese Foundation for Science and Technology (FCT) within the scope of the projects Refa UIDB/00681/2020 and Refa UIDB/00742/2020. Furthermore, we would like to thank the CI\&DETS, CERNAS and UICISA: E Research Centres and the Polytechnic Institutes of Viseu for their support.

Nada BOUSTANI is currently an associate professor in the Faculty of Business \& Management at Saint-Joseph University- Beirut and also coordinator of the 1st year Master program's curriculum. She is an active member in different international research associations such as AIS, MENA-AIS, and an engaged researcher with published papers related to innovation in Finance and Business fields. In addition to her academic and research performances. She is a prominent business consultant for several businesses.

ORCID ID: orcid.org/0000-0003-2252-0149

Manuela FERREIRA has been Vice-President of the Polytechnic Institute of Viseu. Coordinator of the Life Sciences and Health Sciences Group, and integrated member of the UICISA research unit: E. Joined several research teams from financed projects. Has published 106 articles in specialized magazines and 96 papers in event proceedings, has 5 book chapters and 2 books published. Participated as a lecturer with oral communications and posters at about a hundred national and international scientific events. She has about two hundred scientific papers published in co-authorship.

ORCID ID: orcid.org/0000-0002-8452-2222

Raquel GUINÉ is Licensed degree in Chemical Engineering (1991), MsC in Engineering Science (1997), PhD in Chemical Engineering (2005), all at the Faculty of Science and Technology of the University of Coimbra (Portugal). Teaching Habilitation in Food Science (2015) from the University of Algarve (Portugal). Certificate of Proficiency in English (CPE, 1986) by the University of Cambridge (United Kingdom). University Teacher since 1994, being presently a Coordinating Professor with Habilitation at the Food Industry Department in Polytechnic Institute of Viseu - IPV (Portugal). Has been President of the Scientific Board; President of the Assembly of Representatives; Director of Licence Course, Director of MsC Course, Head of Food Industry Department, all at ESAV, IPV (Portugal). Coordinator of CERNAS-IPV Research Centre at Polytechnic Institute of Viseu.

ORCID ID: orcid.org/0000-0003-0595-6805

Make your research more visible, join the Twitter account of INSIGHTS INTO REGIONAL DEVELOPMENT: @IntoInsights

Copyright (C) 2021 by author(s) and VsI Entrepreneurship and Sustainability Center

This work is licensed under the Creative Commons Attribution International License (CC BY).

http://creativecommons.org/licenses/by/4.0/

(c) (i) Open Access 